\title{
ELLA VON SCHULTZ-ADAIEWSKY AS "A PIONEER OF ETHNOMUSICOLOGY": DISCOVERIES OF THE XIX CENTURY TOGETHER WITH MODERN PRACTICE
}

\begin{abstract}
Ella von Schultz, a pianist, composer and ethnomusicologist, was born in Russia. Western European researchers call her the "pioneer of European ethnomusicology", thus linking her name with the emergence of ethnomusicology in Europe. The research on the music tradition of Resia became her first work and the beginning of her activity as an ethnomusicologist. Resians lived at the foothills of the Alps, on the territory called Venitian Slavia, which had historical and cultural connections with the traditions of Roman, Celtic and Slavic people. The study of the culture of these people of Slavic origin resulted in a scientific work “A journey to Resia and melodies and tunes of Resians' dances". Thus, the idea of comparing lullabies of various ethnic groups (illustrated by Slavic, Czech, Estonian, Italian, French and Norwegian songs) is reflected in the series of her papers "Folk lullabies. Essay of rhythmic and ethnological research". She was the one who suggested the comparative method of research of folklore of different people long before Bela Bartok did so. Ella von Schulz was one of the first to start studying folk culture within the system of all the culture-creating elements: landscape, architecture, traditional costumes, lifestyle, music and poetry. The comparison of notations of folk tunes made by Ella von Schulz with contemporary audio records shows that there are no fundamental differences between them.
\end{abstract}

Keywords: Ella von Schultz-Adaiewsky, pioneer of ethnomusicology, Resia.

Ella von Schultz, a pianist, composer and ethnomusicologist, was born in Russia. Western European researchers call her the "pioneer of European ethnomusicology", thus linking her name with the emergence of ethnomusicology in Europe. In the music science of Germany and Italy, there are scientific papers devoted to Ella von Schultz, as well as a monograph by the German musicologist Renata Husken (Example 1).

Ella's childhood and youth are connected with Saint-Petersburg, where she was born in 1846. When she was born she was named Sophie-Christine-GertrudeElisabeth, which was indicated in the baptism certificate, which took place in the St. Peter's church in the Nevsky prospect.

Thanks to her parents, Ella was blessed with numerous talents. From her father George Julius Schulz, a doctor, writer, polyglot and translator, she inherited a gift of tongues and writing. George Julius Schulz was known as a collector of Estonian and Finnish folklore who translated into German one of the parts of the Estonian Kalevipoeg epos. He saw his mission in "helping people to know each other and teaching them to love each other".

Since her early age, Ella practiced piano playing with the help of her mother Johanna Katharina Theodora, who was a good musician and took lessons from the Petersburg pianist Adolf Genselt. At the age of 15-16, Ella performed her first 
concert, which was a big success. At that time, in 1862, she entered Petersburg Conservatory which was just opened by Anton Rubinstein.

The Conservatory faculty was quite influential. Ella was in the piano class of Alexandre Dreishok and her teacher in orchestration and composition was Nikolay Zaremba, who was also teaching Piotr Tchaikovsky, Vasily Safonov, German Larosh and Konstantin Galler at that time. The history of music was taught by Alexandre Faminitsin (Example 2). The personality of this man, who was one of the first researchers of Russian and Slavic folklore and an expert in folk music instruments, definitely influenced the talented student.

In the 1870's Ella von Schultz started her solo career. It was just at that time when her artistic stage name "Adaiewsky" appeared. The letters in this stage name are connected with the music tones of the kettle drum beats in the overture to "Ruslan and Liudmila" by Mikhail Glinka: "a" - "d" - "e". The pianist performed concerts in Russia, Poland, Germany, England, France. In Paris she met and spoke with a composer and music historian Louis Albert Bourgault - Ducoudry, an expert in Greek music and the author of a collection of Greek folk songs. The young musician debated with him on some topics concerning the music of ancient Greeks.

During her life Ella von Schultz had creative contacts with many famous European musicians: Charles Gounod, Franz Liszt, Richard Wagner, Clara Schumann. Her activities as a musician were extremely diverse: she had solo performances, composed music in different genres (including the opera genre), wrote articles in musicology and reviews.

The state of her health and family circumstances forced Ella to leave for Venice with the family of her sister, the artist named Pauline Geiger. The Italian period, which lasted for almost 30 years from 1880 to 1910, opened for her the world of folk music, which she was so passionate about, both as a collector and as a researcher.

In 1883, during her summer holidays in Tarcento, Friuli-Venice-Julia region, Adaiewsky got interested in the culture of Resia people. Resians lived at the foothills of the Alps, on the territory called Venitian Slavia, which had historical and cultural connections with the traditions of Roman, Celtic and Slavic people.

Initially, Adaiewsky was interested with the legends of Russians who had once visited Resia, and whose language was understandable for Resians. The research on the music tradition of Resia became her first work and the beginning of her activity as an ethnomusicologist. Mountainous landscape, and hard to reach locations provided viability of the cultural tradition of these picturesque areas which excited the Russian musician with its originality. 27 notations of instrumental tunes of songs made by Ella were included in the Collection of Materials for the SouthSlavic dialectology and ethnography by Ivan Baudouin de Courtenay, an outstanding Russian linguist of Polish origin and professor at Petersburg University.

The study of the culture of these people of Slavic origin resulted in a scientific work "A journey to Resia and melodies and tunes of Resians' dances". The manuscript was kept by Ella's grandnephew Benno Geiger, a well-known journalist, which was published in 2012 by the Italian musicians from Sergio Gaggia Music association: Febo Guizzi, Giuzeppe Frappa and Andrea Rucli. The research devoted to the Resian folklore contains about 30 tune notations. This work 
is of an extreme value as it is one of the earliest descriptions of the Resian culture, and notations by Ella Adaiewsky are the first notations of the instrumental and vocal music on the Slovenian ethno linguistic territory (Example 3).

"The journey to Resia" can be called a regional monograph which gives an idea of the music tradition of Slavic origin that was formed in the Julian/Julius Alps. The scientific work includes "The researcher's diary" (Un viaggio a Resia) describing the everyday life, appearance and character of Resians, the natural landscape, as well as two analytical sections on the rhythmic and melodic specifics of Resian music (II - "Aria di danza resiana", III - "Armonia"). Adaiewsky's materials collected in 1883 represent 36 examples of songs and dance tunes which she heard both in the Resian area (village of Gniva) and from the Resians living in Torcento but originating from the Resian village of Osiacco. These settlements exist even today.

Adaiewsky herself was very critical about her notations thinking that without a phonograph it was impossible to make this work high quality. The same ideas were expressed by Bela Bartok but much later. However, it is these Ella's transcriptions that give us the earliest idea of this unique music culture.

In her research performed mainly in French and German, Ella appealed to the music culture of various European ethnic groups. Aside from her interests in Slavic folk music, studying Resian folklore was one of her most important interests, followed by the folklore music of Northern Italy. Ella was one of the first researches of music rules of the Friullian villotgenere. The Friullians were so grateful to her that they erected a commemorative plaque in the place where she lived saying: "To Ella Adaiewsky (1846-1926), a famous pianist in Europe who in Tarcento, filled her hearth with vilotis".

While she was living in Venice she could not help but not get interested in the songs of pile driving workers. Canto dei battipali are songs performed in the course of work connected with driving piles into the seabed. In the catalogue of her publications we can also find notations of Slovenian songs written down in Piemonte region, Val Torre area.

What was of special importance for Ella von Schulz was Greek and Byzantine music history. And in her research she preferred to use music terms from Greek sources. Among her works on the subject are the following articles and compositions:

a) articles: "Affinity of Slavic songs and ancient Greek music" ("De l'affinité des Chants slaves et de l'ancienne Musique greque"), published in the "Works of Veneto Royal Institute of sciences, literature and arts"; "The Songs of The EasternGreek Church. Edude" ("Les Chants de l'Église Greque-Orientale. Étude"), published in the Italian music journal "Rivista musicale italiana";

b) chamber music - Greek Sonate for clarinet or violin and piano.

Thus, the idea of comparing lullabies of various ethnic groups (illustrated by Slavic, Czech, Estonian, Italian, French and Norwegian songs) is reflected in the series of her papers "Folk lullabies. Essay of rhythmic and ethnological research". ("La berceuse populaire. Essai d'etude rythmique et etnologique") (RMI, 1894, $1895,1897)$. In these papers she analyses rhythmic, melodic and compositional 
specifics of lullabies, calling them "an ethnological document" and the analysis itself - a "musical anatomy".

In her works, Adaiewsky constantly goes back to the idea of interconnection between the music, the poetic text and the context, as well as various sides of the cultural and natural space she lived in and explored. I believe that folk music represents a deeply individual exspression of the ethnic group from which this group originates from. In her work "A journey to Resia" Ella von Schulz wrote: "It is a difficult and dangerous idea: to describe music of the folk, music of a particular territory. To be completely understood, a folk song should be perceived along with the territory where it was born. Folk songs also include artistic and dramatic elements and implies particular context, as well as a background which is inherent in this very habitat (environment). When signing, people aren'r idle, they are not just singing, but they work or dance, with movements of their hands, which are the same as if they follow the plough. The folk song is not similar to romance nor it evokes confusion, as if it would be performed by a lady or a gentleman in white gloves".

Ella von Schulz was one of the first to analyze folk music from the comparative and historic point of view. Her research was aimed at looking for a "matrix", an image, at something typical. These were the properties which she tried to find at various levels of the music form: rhythm, melody, structure. The development of this method resulted in the so called synoptic tables that compared the notations of the Resian folklore. Julian Strainer (Strajner, 1988) considered that Ella deliberately did not publish all her notations of the melodies but rather selected the most typical ones, which were included in the Baudoin de Courtenay's monograph (Example 5).

In the XX century the studies of the Friulian, Resian folk music was continued by American, Italian and Slovenian researchers from the Congress Library, Washington, Santa Cecilia Academy, Rome and the Institute of Folk Music in Liubliana. Among them were: Alan Lomacs, Giorggio Nataletti, Diego Carpitello, Valens Vodicek, Maria Shushtar, Milco Maticetov, Pablo Mercu, Julian Strainer and others. Comparison of notations of folk tunes made by Ella von Schulz with contemporary audio records shows that there are no fundamental differences between them.

For her time, Ella Adaiewsky was a pioneer. This is confirmed by many researches incuding Roberto Frisano, Gianfranco Ellero, Andrea Rukli and others. In many aspects, she was a real pioneer. She was doing her research and she was looking for her own approaches to researching of materials in a period when no scientific techniques existed in Italy and outside. It was she, who formed up the comparative method of research of folklore of different people long before Bela Bartok. Ella von Schulz was one of the first to start studying folk culture within the system of all the culture-creating elements: landscape, architecture, traditional costume, lifestyle, music and poetry.

Nowadays, the name of Ella von Schulz, a musician from Russia, is becoming more and more famous and takes a worthy place in the history of the European music culture and ethnomusicology. Research works and methods of 
analysis of Ella von Schulz are relevant nowadays. Resian's culture which she studied still exists adapting to new conditions.

\section{LITERATURE}

БОДУЭН-ДЕ-КУРТЕНЭ, И. (1895). Материаль для южнославянской диалектологии и этнографии. 1. Резьянские тексты собрал в 1872, 1873 и 1877 гг., упорядочил и перевел И. А. Бодуэн-де-Куртенэ. С приложениями Эллы фон Шульц-Адаевской. Доложено в заседании Ист.-филол. отд-ния 19 августа 1886 г. Санкт-Петербург: Тип. Имп. Акад. Наук.

ШУЛЬЦ-АДАЕВСКИ, Э. (1904). Напевы и тексты, записанные у терских славян. Санкт-Петербург: Тип. Имп. Акад. Наук. (Отт. из: Бодуэн-де-Куртенэ И. А. Материаль для южнославянской диалектологии и этнографии. Т. 2. Санкт-Петербург. 197-210).

GEIGER, B. (1958). Memorie di un veneziano. Firenze: Vallecchi.

HÜSKEN, R. (2005). Ella Adä̈ewsky (1846-1926): Pianistin, Kompositin, Musikwissenschaftlerin. Köln: Verlag Dohr.

SHOULTZ-ADAÏEWSKY, E. (2008). Atti del Convegni 2007. Musicista Sanpietroburghese nella Tarcento della "Bella epoque". Tarcento: Comune di Tarcento.

SHOULTZ-ADAÏEWSKY, E. (2011). Atti del Convegni 2007-2008, a cura di Umberto Berti; Associazione Musicale Sergio Gaggia, Cividale del Friuli, 126. s.i.p. (con CD).

SHOULTZ-ADAÏEWSKY, E. (1882-1883). "De l'affinité des chants slaves et de l'ancienne musiquie greque". Atti Ist. Ve, s. VI, 41/1, 217-224.

SHOULTZ-ADAÏEWSKY, E. (1894). La Berceuse populaire. Essai d'etude rythmique et etnologique. Rivista musicale Italiana. V. I, 240-256.

SHOULTZ-ADAÏEWSKY, E. (1895a). La Berceuse populaire. Essai d'etude rythmique et etnologique. Rivista musicale Italiana. V. II, 420-448.

SHOULTZ-ADAÏEWSKY, E. (1895b). Vecchia canzone di Natale, raccolata dalla baronessa Olgade Craighernella Carnia (Ligosullo), cantata da pastori secondo una tradizione antica. Rivista delle tradizioni popolari italiane. II, 166-168.

SHOULTZ-ADAÏEWSKY, E. (1901). Les Chants de l'Église Greque-Orientale. Étude. Rivista musicale Italiana, V. VIII. 43-74; 579-602.

STRAJNER, J. (1988). Citira. Musica strumentale in Val di Resia. Udine - Trieste: Pizzicato Edizioni Musicali-Editoriale Stampa Triestina.

UN VOYAGE A RESIA. (2012). Il manoscritto di Ella Adaïewsky del 1883 e la nascita dell'etnomusicologia in Europa, a cura di Febo Guizzi. Trascrizione del manoscritto di Giuseppe Frappa. Libreria Musicale Italiana. 
Ирина Теплова

\section{ЕЛА ВОН ШУЛЦ - АДАЈЕВСКИ КАКО ПИОНЕР НА ЕТНОМУЗИКОЛОГИЈАТА: СОЗНАНИЈА ОД ХІХ ВЕК И МОДЕРНИТЕ ПРАКТИКИ}

Резиме

Ела вон Шулц е една од основачите на етномузикологијата во Европа. Фолклорот на различни европски етнички групи беше во фокусот на нејзината истражувачка кариера. Фолклорот на Италијанците, Британците, Чесите, Келтите и Татарите беше дел од нејзиниот истражувачки фокус. Сепак, славистичкиот фолклор отсекогаш беше нејзин примарен интерес.

Таа ги постави основите за истражување на фолклорната музика на словенските племиња кои живееја на Карнските Алпи.

Транскрипцијата на фолклорните песни и инструменталните музички делови направени во Ресија во 1883 година се првите документирани докази за постоењето на ваква традиционална уникатност. Теориските истражувања на фолклорната култура во Ресија, подготвени од Конзерваториумот во Санкт Петербург, претставуваат изворно искуство на истражувањето на фолклорниот комплекс во споменатиот регион.

Ела вон Шулц ќe остане запаметена поради нејзиното истражување на специфичниот „музички јазик“ којшто е својствен за различни народи. Затоа, таа се смета за пионер на компаративниот метод на истражување во етномузикологијата.

\section{Illustrations}

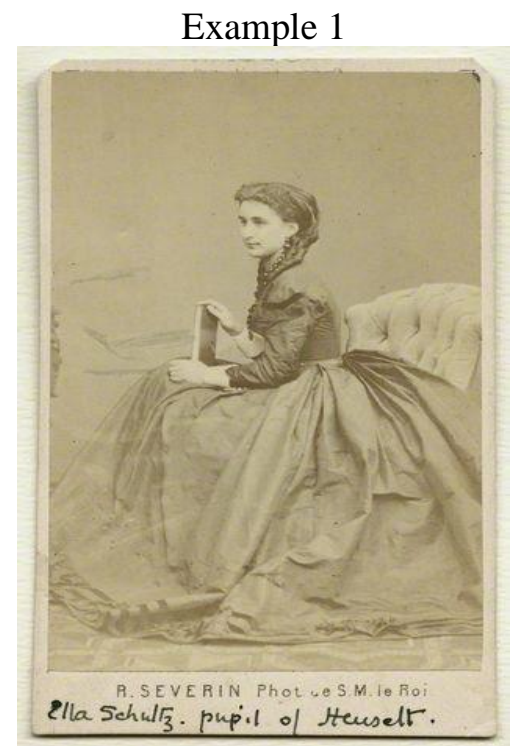

Ella von Schulz-Adayevsky (1846-1826) - a pianist, composer and ethnomusicologist 


\section{Example 2}

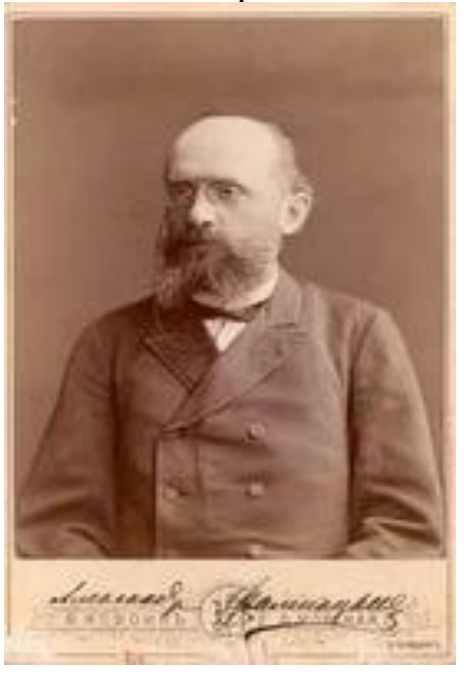

Alexandre Faminitsin (1841-1896) - music historian, professor of the St. Petersburg Conservatory

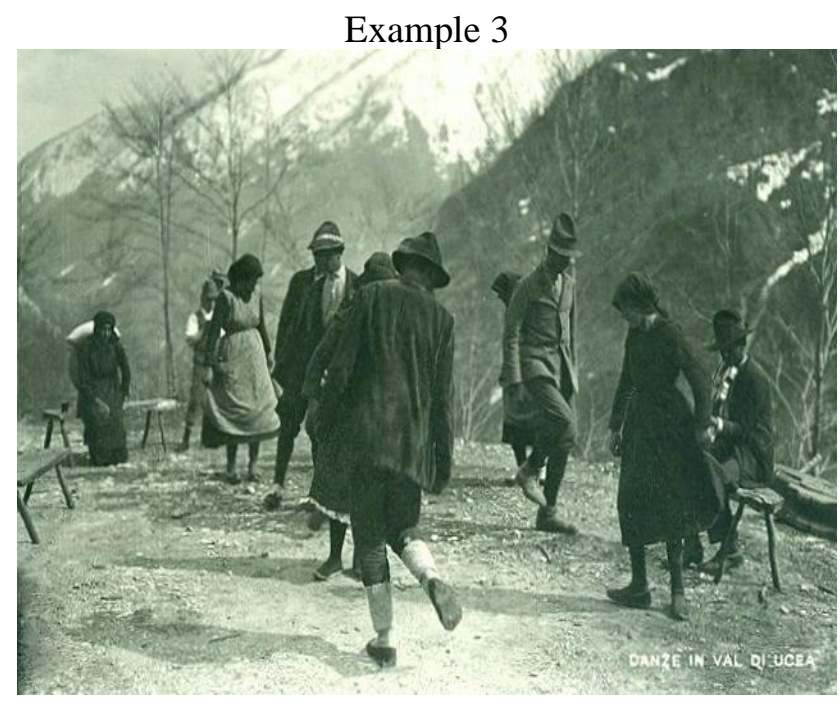

Rezian dance, 1922. Photo of the Udine Museum of Ethnography (Friuli-Venezia Giulia) 


\section{Example 4}

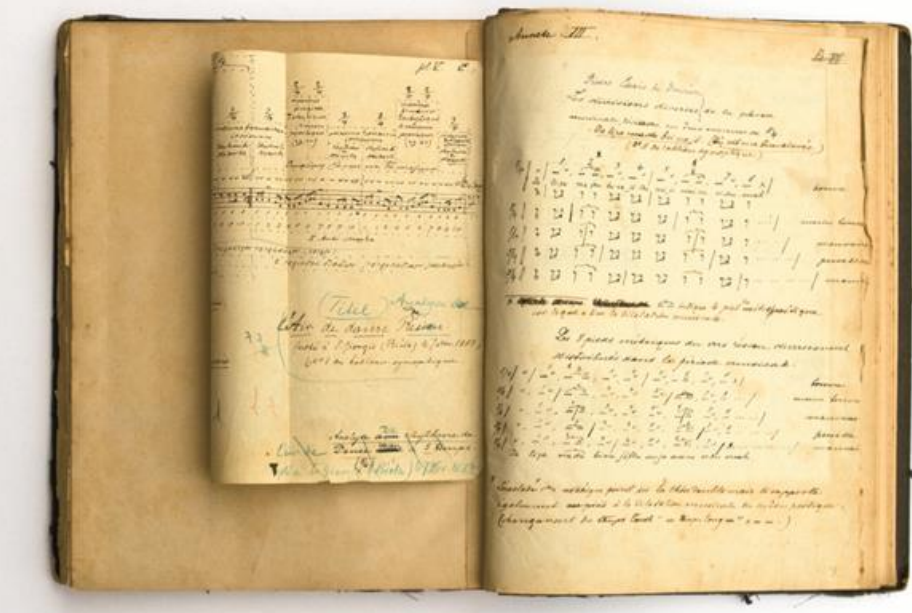

Notation of Resian music and synoptic tables by Ella von Schulz Adaevskaya. Manuscrtpt: "A journey to Resia and melodies and tunes of Resians' dances".

Example 5

\section{Recueillis en 1887.}

Mi 24 (1). Ta Osốjska (di Oseacco). Aria di ballo di Simeone di Leonardo Voglitj. [Text N $^{1377.1 .]}$
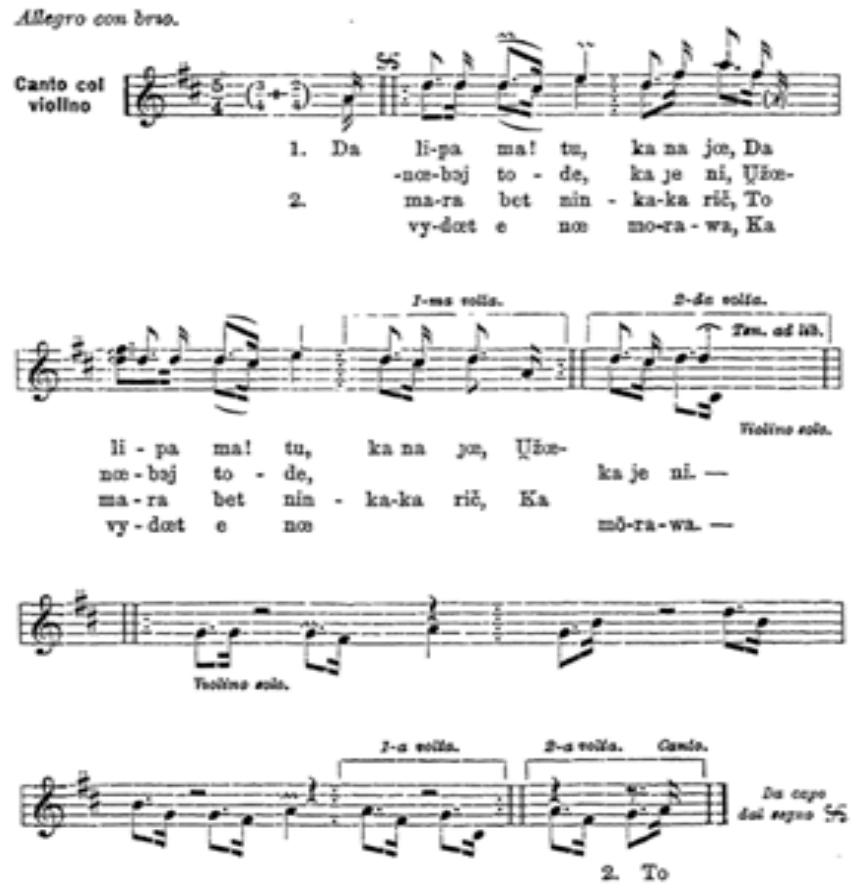
Бодуэн-де-Куртенэ, И. Материалы для южнославянской диалектологии и этнографии.

1. Резьянские тексты собрал в 1872, 1873 и 1877 г., упорядочил и перевел И.А. Бодуэн-де-Куртенэ. С приложениями Элли фон Шульц-Адаевской. Доложено в заседании Ист.-филол. отд-ния 19 августа 1886 г. - СПб.: тип. Имп. АН, 1895. - [4], XLVII, C. 485. 